УДК 656.078

UDC 656.078

Попович Д.П. ${ }^{1}$, Петриків А.Р. ${ }^{1}$, Чепесюк Л. В. ${ }^{1}$,Шевчук О.С. ${ }^{2}$, Фалович Н.М.' ${ }^{2}$, Маяк М.М. ${ }^{3}$, Петринюк Н.А. ${ }^{2}$.

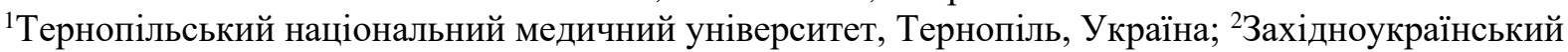

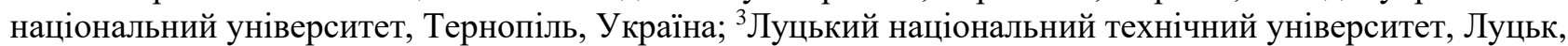
Україна

\title{
ВИМІРЮВАННЯ КОМФОРТУ В ГРОМАДСЬКОМУ ТРАНСПОРТІ
}

\begin{abstract}
Хоча комфорт є одним 3 найважливіших чинників, що формують попит на громадський транспорт, чинники зручності часто не помічаються при проектуванні транспортної мережі та оцінці ефективності. У міському пасажирському транспорті, особливо у містах середнього розміру, вибір способу подорожі пасажирів залежить від багатьох важливих показників, окрім тривалості подорожі. Для того, щоб покращити розуміння кількісних та якісних показників у використанні громадського транспорту, дизайн транспортних послуг повинен відповідати рівню обслуговування, очікуваному клієнтами, що забезпечить найкращу капіталізацію впровадження транспортних послуг. Це дослідження є основою для формулювання політики пасажирських перевезень у громадському транспорті з точки зору максимального комфорту населення та розробило основу для вимірювання найважливіших факторів зручності громадського транспорту, мінімального дискомфорту та максимальної безпеки. На основі польових досліджень із застосуванням детермінант дискомфорту та ваги визначено кількісний показник сприйняття комфорту в мережі громадського транспорту Тернополя, за допомогою якого можна прогнозувати поведінку пасажирів при користуванні міським громадським транспортом. Такий показник можна використовувати для прогнозування поведінки пасажирів під час користування громадським транспортом. Результати дослідження можуть бути використані як інструмент для планування та функціонування міської транспортної мережі. Визначення загального комфорту системи громадського транспорту $є$ змінним, що залежить від факторів, найважливішим 3 яких $\epsilon$ щільність пасажирів у салонах переповнених транспортних засобів. 3 огляду на багатостандартний аналіз транспортної мережі типових міст, показників руху громади - дискомфорту, завантаженості транспортних засобів, середнього часу руху, середньої відстані, оптимізаційний проект мережі громадського транспорту рекомендується розглядати цю групу індикатори комфорту. Результати дослідження є основою для розуміння ставлення пасажирів та сприйняття комфорту громадського транспорту та можуть бути використані як інструмент для планування та функціонування мережі міського транспорту середніх розмірів.

Ключові слова: пасажирські перевезення, маршрут, рівень комфорту, громадський транспорт, пасажиропотік, транспортна мережа
\end{abstract}

\section{ВСТУП}

На основі польових досліджень із застосуванням детермінант дискомфорту та ваги визначено кількісний показник сприйняття комфорту в мережі громадського транспорту Тернополя, за допомогою якого можна прогнозувати поведінку пасажирів при користуванні міським громадським транспортом. Визначення загального комфорту системи громадського транспорту Тернополя залежить від багатьох факторів, найважливішим з яких $є$ щільність пасажирів у салоні в години пік, хоча для оптимального проектування мережі громадського транспорту рекомендується враховувати багато показників комфорту. Результати дослідження є основою для розуміння ставлення пасажирів та сприйняття комфорту громадського транспорту та можуть бути використані як інструмент для планування та функціонування мережі міського транспорту середніх розмірів.

\section{АНАЛІЗ ЛІТЕРАТУРНИХ ДАНИХ ТА ПОСТАНОВКА ПРОБЛЕМИ}

Щоб підвищити рівень безпеки та зменшити дискомфорт у громадському транспорті, дизайн транспортних послуг має максимально відповідати очікуванням пасажирів [1-9]. Дослідження 3 використанням моделі дискомфорту можуть дозволити пасажирам правильно спрогнозувати вибір транспорту та їхню поведінку під час користування громадським транспортом у середніх містах, але вони мають певні очевидні недоліки - дослідження пасажиропотоку - це інформаційна послуга за допомогою непрямих методів $[9,10,11,12]$, на цій основі, через неточність і припущення, щоб оцінити задоволеність пасажирів на основі ряду факторів, таких як зручність, доступність, інформація, час/тривалість, обслуговування клієнтів, комфорт водіння, безпека та вплив на навколишнє середовище, відбудеться багато серйозних помилок. ISO 2631-1 регулює відповідність механічних параметрів (рівень шуму котячих коліс тощо), тому його використовують у проектуванні транспортних засобів. Як ми всі знаємо, в Україні при проектуванні транспортної мережі враховується лише час подорожі пасажирів до пункту призначення. Хоча зручність і безпека пасажирів $є$ основними чинниками попиту на громадський транспорт, такі показники, як зручність, 
часто ігноруються при проектуванні середніх транспортних систем. На практиці вибір пасажирів громадського транспорту визначається багатьма факторами.

\section{ЦІЛ ТА ЗАДАЧІ ДОСЛІДЖЕННЯ}

Як ми всі знаємо: мережа маршрутів - це сукупність усіх маршрутів маршруту громадського пасажирського транспорту. Беручи до уваги обмеження руху в будь -якому напрямку, маршрут - це напрямок руху транспортного засобу між відправною точкою та кінцевою станцією та відправною точкою є точка стартового транспортного засобу. Під час початкової зупинки в літак сідають пасажири. Проміжна точка зупинки використовується для зупинки транспортного засобу, щоб пасажири могли сісти та вийти. Кінцева зупинка є кінцевою точкою, де транспортний засіб рухається по маршруту. Під час простою пасажири висадилися. Обертовий політ-рух літака вперед і назад від початкової точки до кінцевої точки зупинки. В Україні існує близько 70 міст [3, 4], які можна віднести до середніх [3] з населенням від 50000 до 300000 у містах площею 65 квадратних кілометрів. Для таких міст, як Тернопіль, основний пасажиропотік характеризується радіальним або радіальним, а щільність населення знаходиться в межах 113,1 людини на квадратний кілометр. Відповідно до пунктів [5, 6, 7, 8], у місті є 38 транспортних зон, а загалом 37 автобусних маршрутів громадського транспорту обслуговують 197 одиниць. Автобусів, кількість зупинок-218 одиниць, загальна довжина мережі автобусних маршрутів-647,7 км. Визначено, що автобусний парк громадського транспорту обладнаний автомобілями "Богдан А092", "Еталон" та іншими невеликими легковими автомобілями, кожен з яких може перевозити 42 пасажири. Перевантаження транспорту спостерігається в години пік у всіх мережах громадського транспорту-коефіцієнт заповнення перевищує 100\%,причому середньодобовий коефіцієнт знаходився в межах 60-80\%.

Під пасажиропотоком розуміється навантаження на мережу ліній у напрямку руху пасажирів за певний проміжок часу (години, дні). особливість:- Він змінюється в залежності від годин дня, днів тижня, довжини маршруту та напрямку руху;: Характеризується нерівномірністю в часі та просторі. Метою даної роботи $\epsilon$ отримання вихідних даних для дослідження пасажиропотоку на Тернопільському пасажирському маршруті загального користування. Період розслідування: 10.09.2020-14.09.2020.Час іспиту: 6:30-19:30. Тип іспиту:- Підрахуйте кількість пасажирів, які сідають/виходять на кожній зупинці.- Обстеження пасажирів у великих транспортних вузлах. Об'єкт огляду: літак обертається і летить. Об'єкт огляду: літак обертається і летить. Період розслідування:

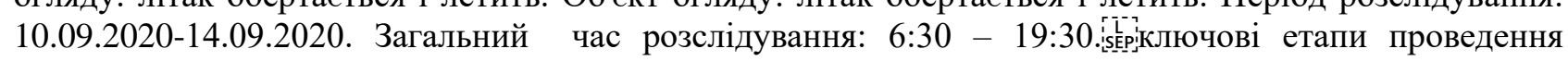
обстеження:

- ранковий період «пік»: 6:30 - 10:00 - мінімум 2 обертових рейса на одному маршруті.

- міжпіковий період: 10:00 - 16:00 - мінімум 2 обертових рейса на одному маршруті.

- вечірній період «пік»: 16:00 - 19:30 - мінімум 2 обертових рейса на одному маршруті.

Як ми всі знаємо, у міських пасажирських перевезеннях рекомендується заповнити салон на 16 осіб відповідно до максимальної місткості пасажирів, передбаченої конструкцією транспортного засобу. Необхідно вдосконалити політику міського транспорту, щоб комфорт громадського транспорту досяг найкращого рівня-це єдиний показник, який впливає на вибір пасажирами перевезень [9-11]. Дослідження проводилося у два етапи-внутрішній та експериментальний-для збору та обробки даних, отриманих під час обстежень пасажиропотоку. Постійне польове дослідження табличним методом $\epsilon$ найбільш трудомістким у порівнянні з існуючими методами, але єдиним, яке може забезпечити найбільш точну інформацію про пасажирів для подальшої внутрішньої обробки статистичних даних досліджуваної системи громадського транспорту Тернопільський автобусний маршрут. Важливо, що дані досліджень пасажиропотоку на маршрутах громадського транспорту міста Тернополя проводяться як безперервне природне дослідження за допомогою табличного методу. Для аналізу вивчаються шість ротаційних рейсів на кожному існуючому маршруті міської транспортної мережі: пік ранку-з 6.30 до 10.00, період піку-з 10.00 до 16.00, пік вечора-з 16.00 до 19.30. Характеристики пасажиропотоку базуються на годинах доби, днях тижня, нерівномірності потоку пасажирів у часі та просторі від станції відправлення до терміналу в місті, а також оцінці основної пересадки міста. бали та спосіб оплати проїзду Спосіб: готівковий або безконтактний, пільговий. Навчальний період - 7 календарних днів, з 04.11.19 по 11.11.19, для визначення зміни пасажиропотоку у будні та вихідні відповідно. Час: 6.30-19.30 У салоні є бухгалтер, який працює на маршрутному транспорті з першої зупинки, за задніми дверима автобуса. Всі отримані дані про пасажирообіг і способи оплати, а також інформацію про досліджуваний вид перевезення, номер маршруту, напрямок руху транспортних засобів вперед або назад, час початку і закінчення, час між автобусними зупинками, локомотиви, транспортні засоби, облік самостійно, 
фактично записані на обліковій картці, сформованій дослідниками. Згідно 3 дослідженнями, кількість хвилин, які пасажири вважають найкраще витратити на маршрут. Дослідження мережі громадського транспорту Тернополя визначило основні основні показники мобільності пасажирів. Це може бути типовим показником середніх міст і має хорошу кореляцію $3[1,17]$ :

-Швидкість припливу пасажирів між годинами пік становить 1 прохід / хв, а піковий час -4 проходи / хв.;

-Час очікування автомобіля до 10 хвилин;

-Час у дорозі з околиць до центру-30-35 хвилин;

-час подорожі між прилеглими територіями становить до 60 хвилин;

-Піковий час 8.00-9.00, вечір 16.30-18.30;

-Орієнтовна швидкість пасажирів міського автобуса становить 15-20 км/год.

Введіть отриману інформацію на карту облікового запису, яка була сформована для подальшої обробки, а потім обчисліть місце переміщення між зупинками кожного маршруту зйомки інформації (табл. 1)

\section{Анкети для обстеження маршрутів громадського транспорту у місті}

Таблиця 1.

Дата

11.Sep

Маршрут №

$18-3 B$

Початковий пункт

рейсу

Містечко Шляховиків

Кінцевий пункт рейсу

ТРЦ Подоляни

Час початку рейсу $\quad$ 19:00

Вид транспорту: $\quad$ автобус

\begin{tabular}{|c|c|c|c|c|c|c|}
\hline \multirow[t]{2}{*}{ № } & \multirow[t]{2}{*}{ Код } & \multirow[t]{2}{*}{ Зупиночний пункт (ЗП) } & \multicolumn{2}{|c|}{ Кількість пасажирів } & \multirow[t]{2}{*}{$\begin{array}{l}\text { Спосіб } \\
\text { оплати } \\
\text { проїзду }\end{array}$} & \multirow[t]{2}{*}{$\begin{array}{c}\text { Час } \\
\text { простою }\end{array}$} \\
\hline & & & зайшло & вийшло & & \\
\hline 1 & 2 & 3 & 4 & 4 & 6 & 7 \\
\hline 1 & 9692 & Містечко Шляховиків & 2 & & $2 \Gamma$ & \\
\hline 2 & 9693 & с. Велика Березовиця & 2 & & $2 \mathrm{e}$ & \\
\hline 3 & 959 & Газопровід & 1 & & $1 \mathrm{e}$ & \\
\hline 4 & 941 & Цукровий завод & 4 & & $1 г 3 \mathrm{e}$ & \\
\hline 5 & 9694 & АТП-1961 & & 2 & & \\
\hline 6 & 9695 & Тубдиспансер & 1 & 1 & $1 \mathrm{e}$ & \\
\hline 7 & 9696 & ПАТ Ватра & 1 & 5 & $1 \mathrm{e}$ & \\
\hline 1 & 2 & 3 & 4 & 4 & 6 & 7 \\
\hline 8 & 9764 & $\mathrm{CTO}$ & 2 & & $1 \Gamma 1 \mathrm{e}$ & \\
\hline 9 & 9747 & АТП-16154 & 6 & 5 & $6 e$ & \\
\hline 10 & 169 & вул. Князя Остроського & 6 & 7 & $3 г 3 \mathrm{e}$ & \\
\hline 11 & 20 & Міська лікарня №1 & 5 & & $5 \mathrm{e}$ & \\
\hline 12 & 138 & Стадіон & 4 & 1 & $4 \mathrm{e}$ & \\
\hline 13 & 6500 & Обласна лікарня & 2 & 5 & $2 \Gamma$ & \\
\hline 14 & 9702 & вул. Слівенська & 2 & & $1 \Gamma 1 \mathrm{e}$ & \\
\hline 15 & 9698 & вул. Монастирського & 10 & & $3 г 7 \mathrm{e}$ & \\
\hline 16 & 27 & вул. Лесі Українки & 6 & 8 & $6 e$ & \\
\hline 17 & 3600 & Школа №14 & 4 & 6 & $1 \Gamma 3 \Gamma$ & \\
\hline 18 & 553 & пр. Степана Бандери & 2 & 1 & $2 \Gamma$ & \\
\hline
\end{tabular}


( ) Попович Д.П., Петриків А.Р., Чепесюк Л. В., Шевчук О.С., Фалович Н.М., Маяк М.М., Петринюк Н.А. 2021

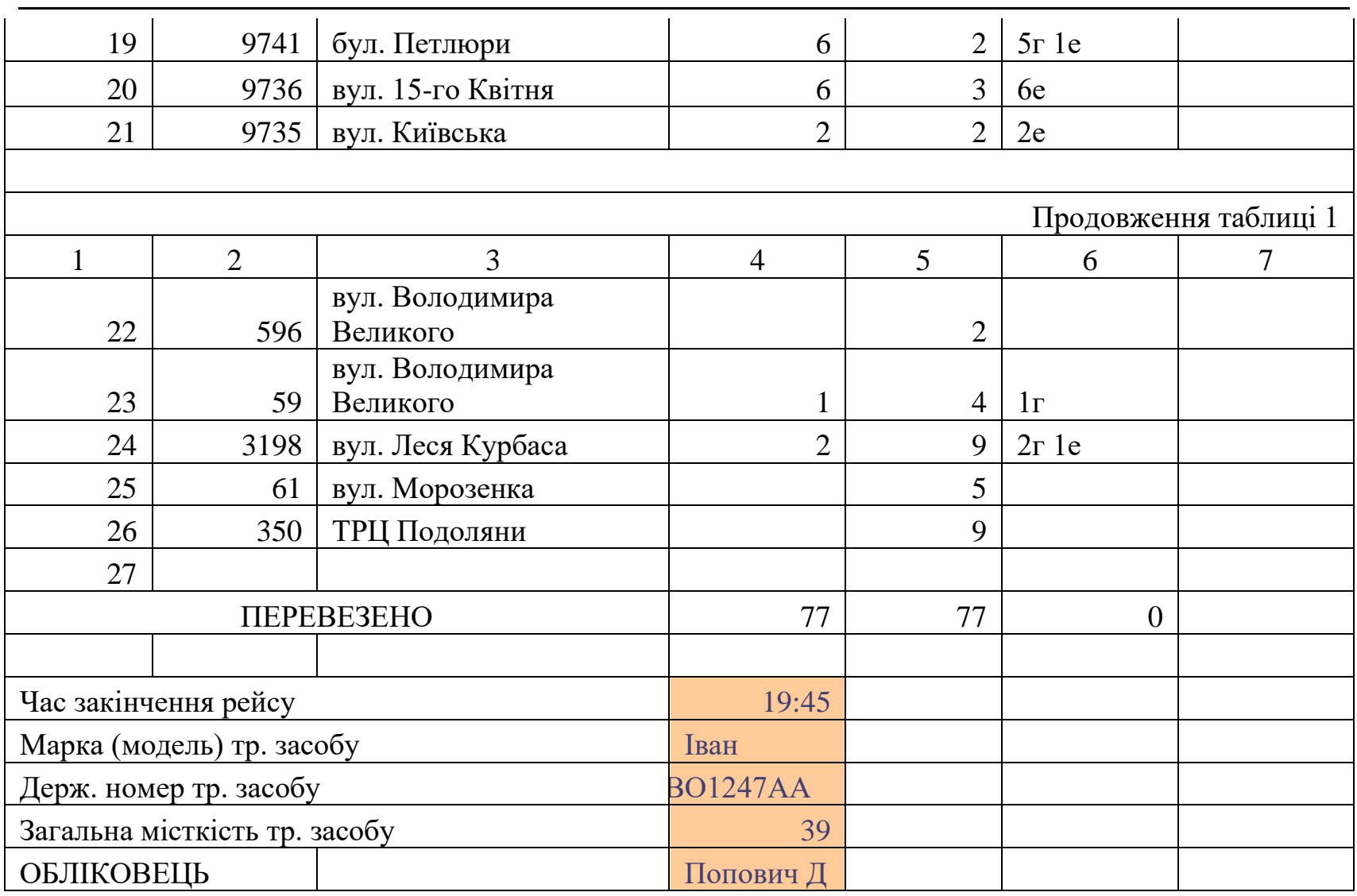

Дослідження мережі громадського транспорту Тернополя визначило основні основні показники мобільності пасажирів. Це може бути типовим показником середніх міст і має хорошу кореляцію 3 [17 17], наприклад, більше нуля, менше 45 та бажано 16 -Згідно $з$ дослідженнями, кількість хвилин, які пасажири вважають найкраще витратити на маршрут. так: -Швидкість припливу пасажирів між годинами пік становить 1 прохід / хв, а піковий час -4 проходи / хв. -Час очікування автомобіля до 10 хвилин; -Час у дорозі з околиць до центру-30-35 хвилин; -час подорожі між між собою. [17 5], Дослідження показують, що, крім пільгових груп, безконтактні (банківська картка, Google Pay) тарифи становлять від $60 \%$ до $74 \%$ від загальної кількості пасажирів, що оплачують проїзд. Транспортні засоби між ділянками міських доріг, для всіх суб’єктів, в межах 2-2,3 хвилин, в залежності від дорожньої ситуації, кордоном ділянки дороги є станція громадського транспорту. Багатостандартний аналіз створеної транспортної мережі: коефіцієнт перевезення пасажирів 1,1 ; нелінійний коефіцієнт 1, 76; середній час очікування 5,8 хвилини; коефіцієнт шляху 4,60; середній час у дорозі 33 хвилини; середня відстань у дорозі становить 4,3 кілометра, що відрізняється від раніше дані.

\section{РЕЗУЛЬТАТИ ДОСЛІДЖЕНЬ}

3 точки зору оптимальних стандартів комфорту та розумної оптимізації заторів, громадський транспорт формує оптимальний вибір міської транспортної політики - застосування цих досліджень. 3 точки зору найбільших заторів у замкнутому просторі-маршруті салони $є$ найскладнішими для людей Транспорт . Для цього маршруту нелінійний коефіцієнт, середній час очікування, середній час у дорозі та середня відстань подорожі вище, ніж вище середнього. 

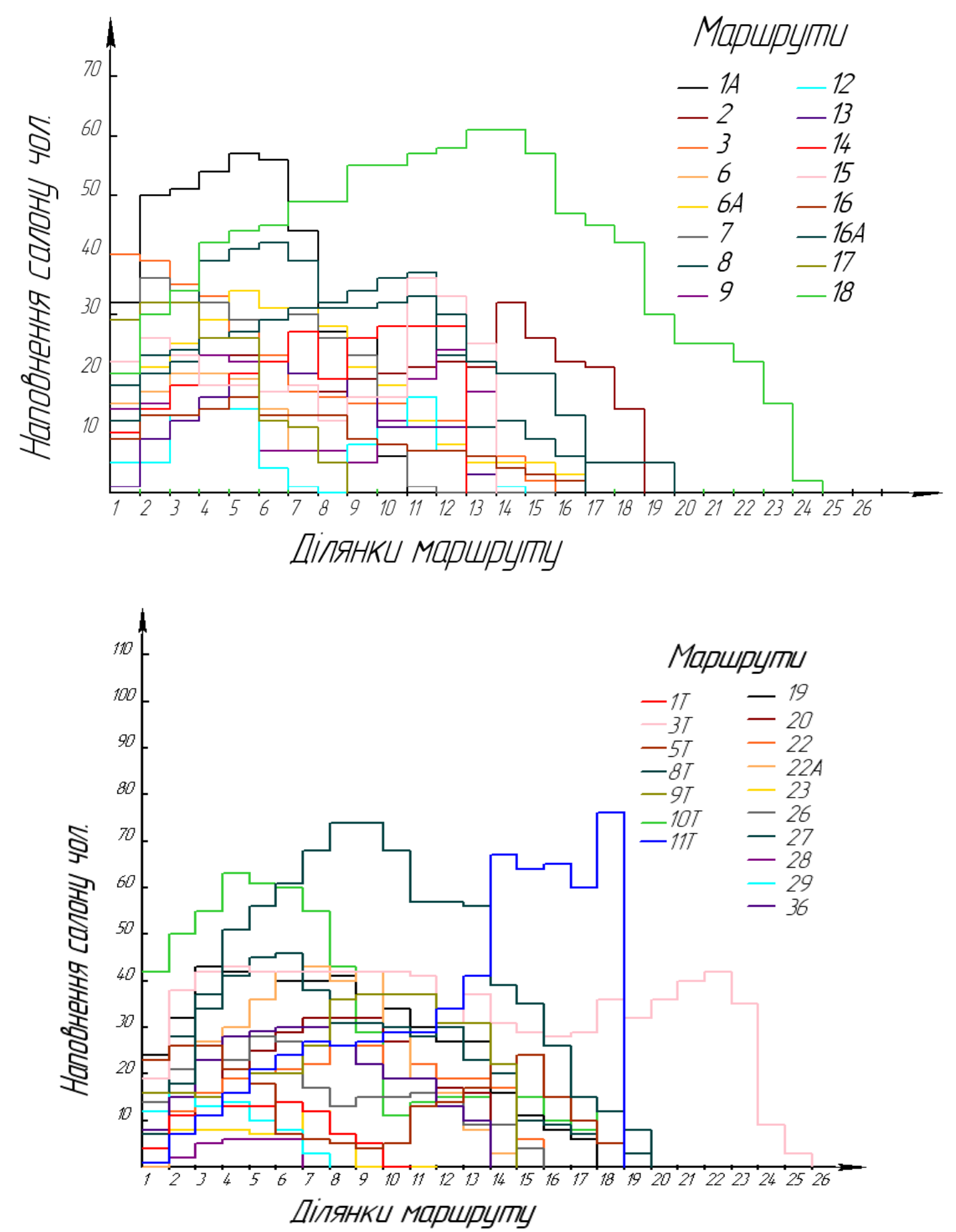

Рисунок 1. Нерівномірність пасажиропотоку за ділянками маршрутів

У [17 9], розрахунок функції переповненості як функції дискомфорту враховує кількість пасажирів, кількість місць і тривалість поїздки. Враховуючи різні варіанти проїзду, перший не має вільних місць, другий - одне місце, а третій варіант, через велику кількість пасажирів, використовується $100 \%$ пасажиромісткості транспортного засобу. У роботі [10], рекомендується оцінювати ступінь переповненості, вимірюючи значення коефіцієнта завантаженості та кількості стоячих пасажирів на квадратний метр, хоча це число зазвичай стандартизовано і враховується виробником автомобіля на етапі проектування. Буде перевищувати умови таке порогове значення, але за законом показників [17 10] функція буде незручною. Можливо, доцільно апроксимувати закон варіації функції дискомфорту за допомогою полінома третього (четвертого) ступеня,моделюючи дану ситуацію. 
Щоб відобразити сприйняття пасажирами комфорту громадського транспорту, у [17 11] дискомфорт лінійно зростає до порогу, а при його перевищенні - експоненціально. Ступінь дискомфорту на малюнках 2 і $3 є$ функцією розрахованої щільності пасажирів у вагоні [17 11]

$$
x=\left\{\begin{array}{c}
\alpha \\
e^{\alpha}
\end{array} \text { if } \begin{array}{c}
\alpha \leq 1 \\
\alpha>1
\end{array}(1)\right.
$$

де рівень кількості пасажирів в транспортному засобі (х) обчислюється на основі показника

$$
\alpha=\frac{\text { Number of passengers in vecicle }}{\text { Vecicle capacity }}(2)
$$

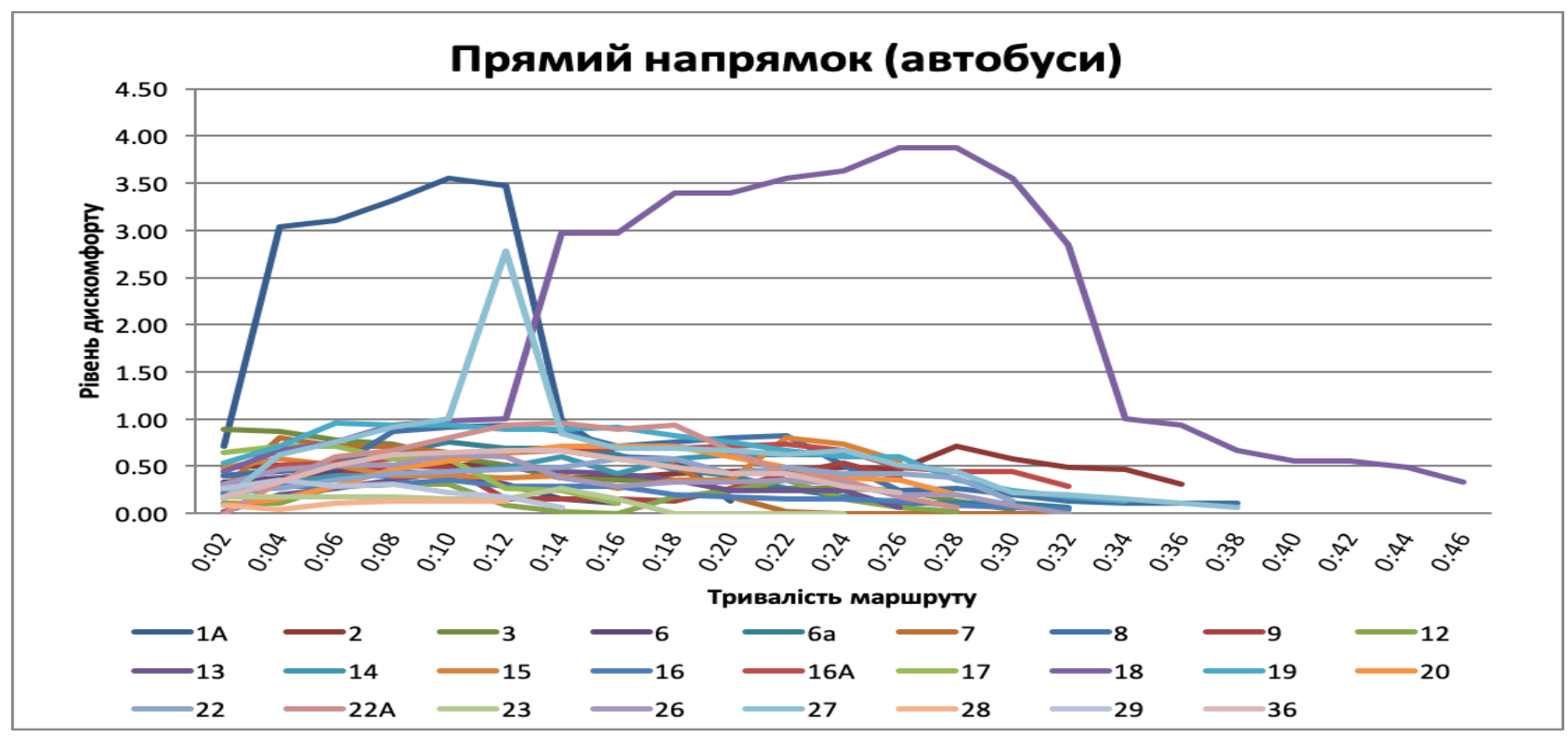

Рисунок 2. Загальний рівень дискомфорту (автобуси) як функція щільності пасажирів за часом у поїздці маршрутом громадського пасажирського транспорту

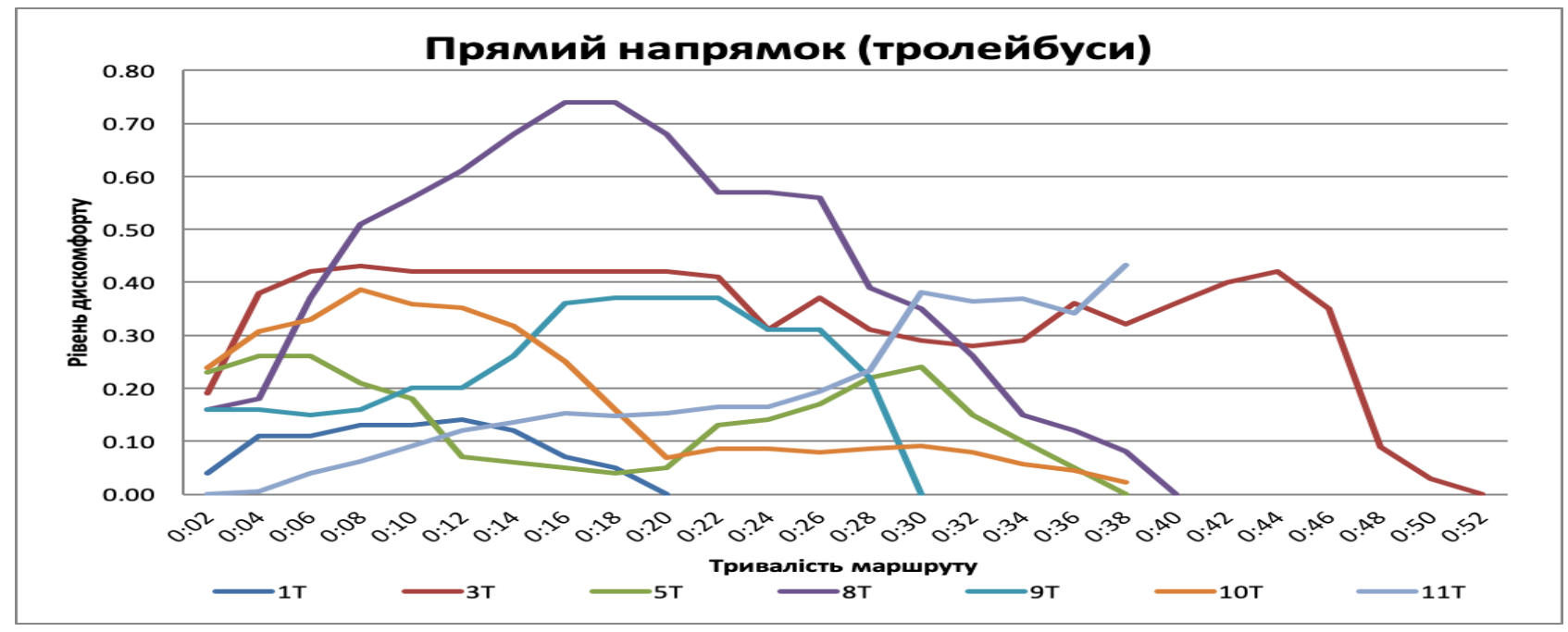

Рисунок 3. Загальний рівень дискомфорту як функція щільності пасажирів за часом у поїздці маршрутом громадського пасажирського транспорту

У реалізації (1) і (2) на рисунках 2, 3 і 4 графічно показано функціональний зв'язок між загальним дискомфортом і щільністю пасажирів у транспортному засобі, на прямих і зворотних маршрутах визначеного досліджуваного режиму перевезення. Для подальшої оцінки дискомфорту рекомендується використовувати метод зважування, який дозволить отримати кусково-лінійну форму, а загальний рівень дискомфорту пасажирів у вагоні під час перевезення [17 11]

$$
f(x)=\sum_{i} w_{i} \cdot x_{i t}(3)
$$


де $x_{i t}$ - значення $i$-го визначника дискомфорту в $t$-й відлік часу, $w_{i}$ - величина $i$-го вагового коефіцієнта, $x_{i t}$ обчислюється $3(1)$.

За словами слідчих, які проводили опитування в Тернополі, при виборі легкового автомобіля та можливих маршрутів важливо вимірювати рівень комфорту від сидіння до подорожі. Опитані пасажири сподіваються комфортно пересуватися в салоні. Ступінь низький. Беручи до уваги дані опитування, а також дані дослідження Şükrü İmre та Dilay Çelebi [17, 11], ми прийняли значення комфорту сидіння 0,0556 , що, очевидно, пов'язане з рівнем комфорту сидіння 0,0615 для Т1 і 0,0762 для М2 $[1,17,11]$. Отже, значення вагового коефіцієнта становить: завантаженість транспортного засобу 0,4053 ; температура транспортного засобу 0,2243 , комфорт сидіння 0,0556 , інформація та опис 0,0590 ; чистота транспортного засобу 0,1324 ; технічний стан транспортного засобу 0,$0899 ; 0,0335[1$, $17,11]$.

\section{ОБГОВОРЕННЯ РЕЗУЛЬТАТІВ ДОСЛІДЖЕНЬ}

Для маршрутів, що перевищують умовний поріг (Рис. 4): 1А, 18, 22, ступінь дискомфорту аналізується на основі маршруту мережі пасажирського транспорту загального користування.

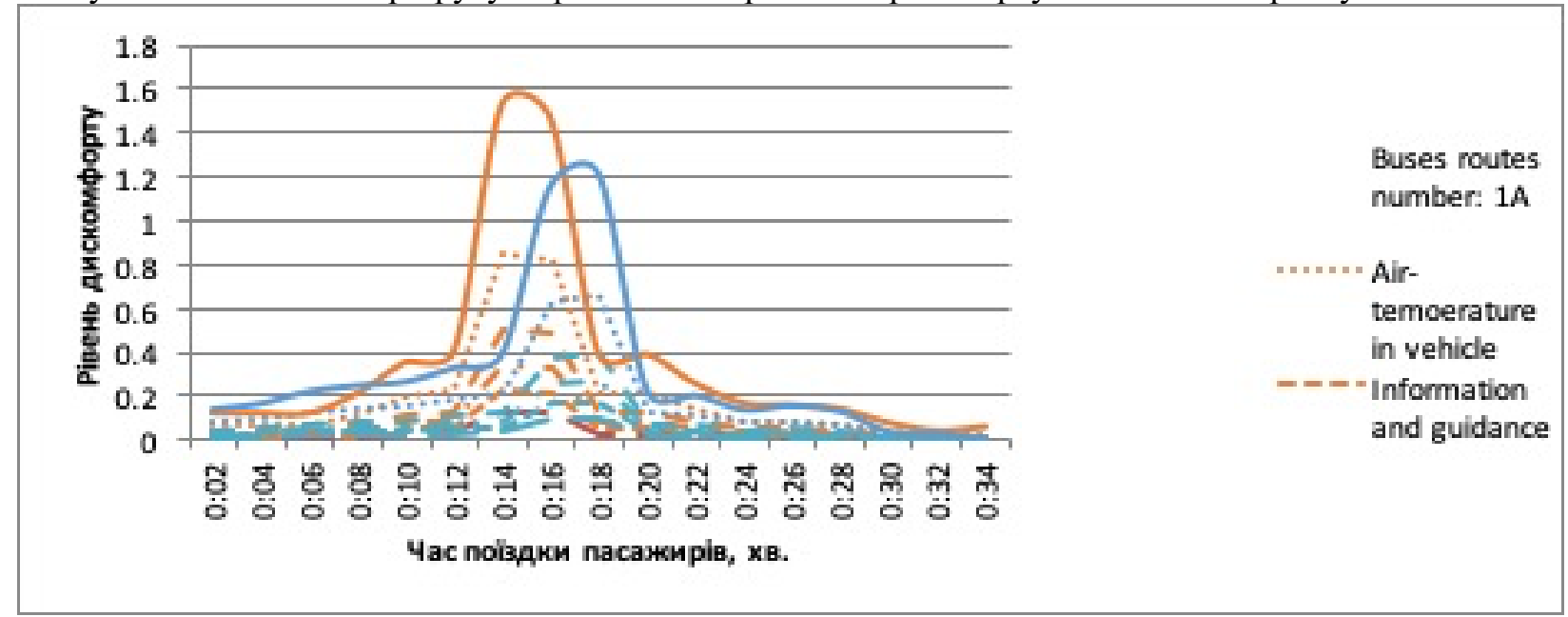

a)

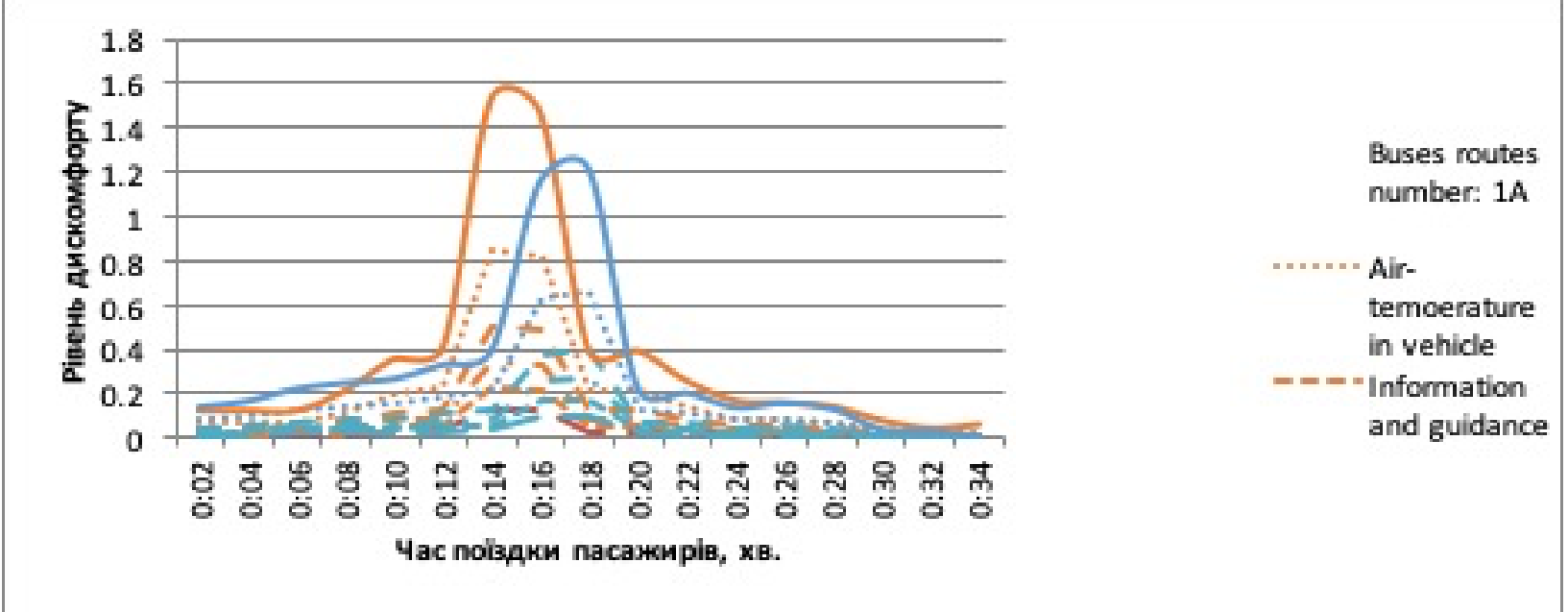

б)

Рисунок 4. Аналіз рівня дискомфорту за часом у поїздці маршрутом громадського пасажирського транспорту: а) прямі маршрути; б) зворотні маршрути

При реалізації (3) рис. 4. компонентний аналіз використовується для вивчення функції дискомфорту під час процесу подорожі прямим і зворотним маршрутом визначеного досліджуваного виду транспорту. Функція дискомфорту під час подорожі показана на рисунках 4 i 5.3 малюнка видно, що кількісний показник комфорту не змінює тривалість поїздки, відповідно до температури повітря в салоні та салону та комфорту сидіння. Однак зручне транспортування не обов'язково означає вибір пасажирів. Індекс також можна використовувати для порівняння комфортності громадського транспорту в конкретному досліджуваному місті. 
Дослідження підтверджує, що приватні автомобілі є дуже важливими, оскільки право власності та подорожі на приватних автомобілях представляють традиційні культурні та психологічні цінності та статус, а самостійне керування $\epsilon$ психологічною перевагою перед громадським транспортом. Тому деякі групи ні довше вибирайте автомобільні телефони.

\section{ВИСНОВКИ}

Попит на міський транспорт є однією з основних потреб, які необхідно задовольнити. На основі польових досліджень детермінант та вагових коефіцієнтів використання комфорту в Тернополі визначено кількісні показники комфортності в мережі громадського транспорту Тернополя, його можна використовувати для прогнозування поведінки пасажирів під час користування громадським транспортом у середніх містах. Результати дослідження можуть бути використані як інструмент для планування та функціонування міської транспортної мережі. Визначення загального комфорту системи громадського транспорту Тернополя $\epsilon$ змінним, що залежить від семи факторів, найважливішим з яких $є$ щільність пасажирів у салонах переповнених транспортних засобів. 3 огляду на багатостандартний аналіз транспортної мережі, типових середніх міст, показників руху громади дискомфорту, завантаженості транспортних засобів, середнього часу руху, середньої відстані, оптимізаційний проект мережі громадського транспорту рекомендується розглядати цю групу індикатори комфорту.

\section{ПЕРЕЛІК ДЖЕРЕЛ ПОСИЛАННЯ}

1.Попович П.В.. Дослідження комфорту в громадському транспорті м. Тернополя. Побережний Л., Мурований І., Шевчук О., та ін. Сучасні технології в машинобудуванні та транспорті. 2020. Том 2. $\mathrm{N}^{\circ} 15$. Ст. 88-98.

2.Шевчук О. С. Порушення при облаштуванні паркувальних місць транспортних засобів на вулично-дорожній мережі міста. Сучасні технології в машинобудуванні та транспорті. 2016. 우 1. C. $167-171$.

3.ДБН Б.2.2-12:2019 Планування та забудова територій. URL: https://dbn.co.ua/pay/pub01/dbn-B2212 planuvannya.pdf

4.http://database.ukrcensus.gov.ua/PXWEB2007/ukr/publ_new1/2019/zb_chnn2019.pdf

5.https://businessforsmartcities.com/load/118/presentation/7_sergiy_nadal_6_852c9.pdf

6.https://www.eway.in.ua/ua/cities/ternopil

7.http://bus.ck.ua/avtobus.html

8.Шевчук О.С. Вплив показників ефективності на безпеку руху вулично-дорожними мережами. Вісник ХНТУСГ. Харків, 2016. № 169. С. 205- 209.

9.Palma, A. d., Kilani, M., \& Proost, S. (2014). Discomfort in mass transit and its implication for scheduling and pricing. Transportation Research Part B , 1-18.

10. Qin, F. (2014). Investigating the In-Vehicle Crowding Cost Functions for Public Transit Modes. Hindawi Publishing Corporation Mathematical Problems in Engineering , 1-13.

11.Şükrü İmre and Dilay Çelebi. Measuring Comfort in Public Transport: A case study for Istanbul. Transportation Research Procedia, 25, 2017. P. 2441-2449.

12.Popovych P, Lyashuk O, Shevchuk O, et al. Influence of organic operation environment on corrosion properties of metal structure materials of vehicles. INMATEH - Agric Eng,52(2), 2017. P. 113118.

13.Lytvynenko, I.V., Maruschak, P.O., Lupenko, Popovych P.V. (2016). Modeling of the Ordered Surface Topography of Statically Deformed Aluminum Alloy. Mater Sciense, 52, 113-122.

14.Popovych, P., Shevchuk, O., Dzyura, V., Poberezhna, L., Dozorskyy, V., Hrytsanchuk, A.(2018). Assessment of the Influence of Corrosive Aggressive Cargo Transportation on Vehicle Reliability. International Journal of Engineering Research in Africa 38, 17-25.

15.Maruschak, P., Poberezny, L., Prentkovskis, O., Bishchak, R., Sorochak, A., \& Baran, D. (2018). Physical and mechanical aspects of corrosion damage of distribution gas pipelines after long-term operation. Journal of failure analysis and prevention, 18(3), 562-567.

16.Yavorskyi, A. V., Karpash, M. O., Zhovtulia, L. Y., Poberezhny, L. Y., Maruschak, P. O., \& Prentkovskis, O. (2016). Risk management of a safe operation of engineering structures in the oil and gas sector. In Proceedings of the 20th International Scientific Conference „Transport Means, 370-373.

17.B. Sokil, O. Lyashuk, M. Sokil, et.al(2018). Dynamic Effect of Cushion Part of Wheeled Vehicles on Their Steerability. International Journal of Automotive and Mechanical Engineering, 15.1, 4880-4892. 
18.Sekulić, D., Dedović, V., Rusov, S., Obradović, A., Šalinić, S. (2016). Definition and determination of the bus oscillatory comfort zones. Int. J. Ind. Ergon. 53, 328-339.

19.https://www.citylab.com/transportation/2020/05/commute-car-traffic-transit-bike-remote-workcoronavirus/611365/?fbclid=IwAR3 Ykbyf9yWC9jJhI5tMk49jecimXa7zsOy1TgBUpBVUM1ZSXeHjNpMS_I

20.Міністерство інфрастуктури України URL: http://www.mintrans.gov.ua

\section{REFERENCES}

1.Pavlo Popovich. Doslidzhennya komfortu v gromads'komu transporti $\mathrm{m}$. Ternopolya //Lyubomir Poberezhnij, Igor Murovanij, Oksana Shevchuk, Pavlo Prognij, Lyubov Poberezhna, Volodimir Plotitsya/ Suchasni tekhnologiï v mashinobuduvanni ta transporti - 2020. - Tom 2 - No 15.- St. 88-98

2.Shevchuk, O.S. (2016). Porushennya pry`oblashtuvanni parkuval`ny`x miscz` transportny`x zasobiv na vuly`chno-dorozhnij merezhi mista. Suchasni texnologiyi v mashy`nobuduvanni ta transporti, 1, 167-171.

3.DBN B.2.2-12:2019 Planuvannya ta zabudova tery`torij: https://dbn.co.ua/pay/pub01/dbn-B-

2212_planuvannya.pdf

4.http://database.ukrcensus.gov.ua/PXWEB2007/ukr/publ_new1/2019/zb_chnn2019.pdf

5.https://businessforsmartcities.com/load/118/presentation/7_sergiy_nadal_6_852c9.pdf

6.https://www.eway.in.ua/ua/cities/ternopil

7.http://bus.ck.ua/avtobus.html

8.Shevchuk, O.S. (2016). Vplyv pokaznykiv efektyvnosti na bezpeku ruhu vulychno-dorozhnymy merezhamy. Visnyk HNTUSG, 169, 205-209.

9.Palma, A. d., Kilani, M., \& Proost, S. (2014). Discomfort in mass transit and its implication for scheduling and pricing. Transportation Research Part B , 1-18.

10.Qin, F. (2014). Investigating the In-Vehicle Crowding Cost Functions for Public Transit Modes. Hindawi Publishing Corporation Mathematical Problems in Engineering , 1-13.

11.Şükrü İmre and Dilay Çelebi. (2017). Measuring Comfort in Public Transport: A case study for Istanbul. Transportation Research Procedia, 25, 2441-2449.

12.Popovych P, Lyashuk O, Shevchuk O, et al. (2017). Influence of organic operation environment on corrosion properties of metal structure materials of vehicles. INMATEH - Agric Eng,52(2), 113-118.

13.Lytvynenko, I.V., Maruschak, P.O., Lupenko, Popovych P.V. (2016). Modeling of the Ordered Surface Topography of Statically Deformed Aluminum Alloy. Mater Sciense, 52, 113-122.

14.Popovych, P., Shevchuk, O., Dzyura, V., Poberezhna, L., Dozorskyy, V., Hrytsanchuk, A.(2018). Assessment of the Influence of Corrosive Aggressive Cargo Transportation on Vehicle Reliability. International Journal of Engineering Research in Africa 38, 17-25.

15.Maruschak, P., Poberezny, L., Prentkovskis, O., Bishchak, R., Sorochak, A., \& Baran, D. (2018). Physical and mechanical aspects of corrosion damage of distribution gas pipelines after long-term operation. Journal of failure analysis and prevention, 18(3), 562-567.

16.Yavorskyi, A. V., Karpash, M. O., Zhovtulia, L. Y., Poberezhny, L. Y., Maruschak, P. O., \& Prentkovskis, O. (2016). Risk management of a safe operation of engineering structures in the oil and gas sector. In Proceedings of the 20th International Scientific Conference „Transport Means, 370-373.

17.B. Sokil, O. Lyashuk, M. Sokil, et.al(2018). Dynamic Effect of Cushion Part of Wheeled Vehicles on Their Steerability. International Journal of Automotive and Mechanical Engineering, 15.1, 4880-4892.

18.Sekulić, D., Dedović, V., Rusov, S., Obradović, A., Šalinić, S. (2016). Definition and determination of the bus oscillatory comfort zones. Int. J. Ind. Ergon. 53, 328-339.

19.https://www.citylab.com/transportation/2020/05/commute-car-traffic-transit-bike-remote-workcoronavirus/611365/?fbclid=IwAR3Ykbyf9yWC9jJhI-

5tMk49jecimXa7zsOy1TgBUpBVUM1ZSXeHjNpMS_I

20.Ministerstvo infrastruktury Ukrai'ny, official website, available at: www.mintrans.gov.ua

D.Popovych, A. Petrykiv, L. Chepesyuk, O. Shevchuk, N. Falovych, M. Maiak, N. Petrinuk. Research of comfort in public transport of Ternopil

Comfort is one of the most important factors shaping the demand for public transport, but convenience factors are often overlooked when designing a transport network and evaluating efficiency. In urban passenger transport, especially in medium-sized cities, the choice of passenger mode depends on many important indicators, in addition to the duration of the trip. In order to improve the understanding of quantitative and qualitative indicators when using public transport, the design of transport services should 
correspond to the level of service expected by customers, which will ensure optimal capitalization of transport services. This study is the basis for public transport to formulate passenger transport policy in terms of maximum comfort of the population and develops a basis for measuring the most important factors of public transport convenience, minimum discomfort and maximum safety.Based on field research on the determinants of discomfort and weight, a quantitative indicator of the perception of comfort in the public transport network of Ternopil was determined, which can be used to predict the behavior of passengers when using public transport. It can be determined that the overall comfort of the public transport system of Ternopil depends on many factors, the most important of which is the density of passengers in cars during rush hour, although it is advisable to optimize the design of public transport network taking into account many comfort indicators. Personal cars are very important because owning and traveling with such vehicles is a traditional cultural and psychological value and status, and self-driving is a psychological advantage over public transport, so some groups stop choosing cars. The results of the study are the basis for understanding the attitude of passengers and the perception of the comfort of urban public transport and can be used as a tool for planning and operation of medium-sized urban transport networks.

Key words: passenger transportation, route, comfort, public transport, passenger transportation^^ transport networks

ПОПОВИЧ Данило Павлович, студент групи ММ-209,Тернопільський національний медичний університет, Тернопіль, Україна, e-mail: popovych danpav@tdmu.edu.ua.

ПЕТРИКІВ Анастасія Романівна, студентка групи ММ-204,Тернопільський національний медичний університет, Тернопіль,Україна, e-mail: petrykiv anarom@tdmu.edu.ua

ЧЕПЕСЮК Леся Степанівна, студентка групи ММ-204, Тернопільський національний медичний університет, Тернопіль, Україна, e-mail: chepesyuk_lesvik@tdmu.edu.ua

ШЕВЧУК Оксана Степанівна, кандидат технічних наук, доцент, доцент кафедри транспорту і логістики, Західноукраїнський національний університет, Тернопіль, Україна, e-mail: oksana_shevchuk84@ukr.net ORCID ID: https://orcid.org/0000-0001-8283-4620

ФАЛОВИЧ Наталя Миколаївна, кандидат економічних наук, доцент, доцент кафедри транспорту і логістики, Західноукраїнський національний університет, Тернопіль, Україна, e-mail: n.falovych@ gmail.com ORCID ID: https://orcid.org/0000-0003-1651-3022

МАЯК Микола Михайлович, доктор технічних наук, професор, професор кафедри автомобілів і транспортних технологій, Луцький національний технічний університет, Луцьк, Україна, e-mail: maiak48@mail.ru

ПЕТРИНЮК Наталя Андріївна, аспірант кафедри транспорту і логістики, Західноукраїнський національний університет, Тернопіль, Україна, e-mail: nshavyko0502@gmail.com

Danylo POPOVYCH, student of MM-209 group, Ternopil National Medical University, Ternopil, Ukraine, e-mail: popovych_danpav@tdmu.edu.ua.

Anastasia PETRYKIV, student of MM-204 group, Ternopil National Medical University, Ternopil, Ukraine, e-mail: petrykiv anarom@tdmu.edu.ua.

Lesya CHEPESYUK, student of MM-204 group, Ternopil National Medical University, Ternopil, Ukraine, e-mail: chepesyuk lesvik@tdmu.edu.ua.

Oksana SHEVCHUK, PhD in Engeneering, Associate Professor of the Department of Transport and Logistics, Western Ukrainian National University e-mail: oksana shevchuk84@ukr.net ORCID ID: https://orcid.org/0000-0001-8283-4620

Nataliia FALOVYCH, PhD in Economic Sciences, Associate Professor of the Department of Transport and Logistics, Western Ukrainian National University e-mail: n.falovych@gmail.com ORCID ID: https://orcid.org/0000-0002-5784-0233

Mykola MAIAK, Doctor of Sciences, Professor, Professor of the Department of Automobiles and Transport Technologies, Lutsk National Technical University, Lutsk, Ukraine, e-mail: maiak48@mail.ruhttps://orcid.org/0000-0002-9749-980X

Natalia PETRYNYUK, Postgraduate Student, Department of Transport and Logistics, Western Ukrainian National University, Ternopil, Ukraine, e-mail: nshavyko0502@gmail.com

DOI 10.36910/automash.v2i17.641 